\title{
Historical Development of Modern Surgery in America
}

\author{
Yeu-Tsu Margaret Lee \\ Department of Surgery, School of Medicine, University of Hawaii, Honolulu, USA \\ Email: ytm_lee@hotmail.com
}

How to cite this paper: Lee, Y.-T. M. (2016). Historical Development of Modern Surgery in America. Advances in Historical Studies, 5, 168-182.

http://dx.doi.org/10.4236/ahs.2016.54015

Received: July 7, 2016

Accepted: September 9, 2016

Published: September 12, 2016

Copyright (c) 2016 by author and Scientific Research Publishing Inc. This work is licensed under the Creative Commons Attribution International License (CC BY 4.0).

http://creativecommons.org/licenses/by/4.0/

\begin{abstract}
Surgeons use operative procedure to save life and to treat patient's disease. Advances are made with new operations and/or designing and modification of surgical instrument. This paper reviews the great surgical advances in the United States in the last century, presented in tabular form and arranged chronologically by year of first publication. Major topics covered include: cancer management, pulmonary, cardiac and vascular surgery, war surgery, care of trauma and burn, minimal invasive and robot surgery, organ transplantation and facial reconstruction, medical and surgical devic-
\end{abstract} es.

\section{Keywords}

Surgery, Historical Development, America, Medical History

\section{Introduction}

"Since the study of medicine is a lifelong learning process, the study of surgical history can contribute to make this educational effort more pleasurable and provide constant invigoration... There's really no way to separate one's own practice from the experiences of all the great surgeons that have gone before", so said the renowned surgical historian, Ira M. Rutkow (Rutkow, 2004).

The discovery of ether and nitrous oxide as inhaled anesthetics should be counted as the dawning of modern surgery. On Oct 16, 1846, William TG Morton, a Boston dentist, persuaded Dr. John Collins Warren (1778-1856), Professor of Surgery at the Massachusetts General Hospital (MGH), to let him administer sulfuric ether to a patient from whom Warren went on to painlessly remove a small congenital vascular tumor of the neck. After the operation, Warren, greatly impressed with the new discovery, uttered his famous words: "Gentlemen, this is no humbug". 
Rutkow (Rutkow, 2004) ably pointed out that the surgical operation became a truly viable therapeutic procedure after the introduction of four fundamental clinical prerequisites identified and understood in the 1880s and 1990s: knowledge of human anatomy; method for controlling bleeding and maintaining hemostasis; general anesthesia; understanding the causes of infection along with methods necessary to achieve an anti-septic and aseptic operating room environment.

America's New England area had a long intellectual tradition and surgeons of Massachusetts made significant contributions to the development of surgery. Dr. J. Collins Warren, son of Dr. John Collins Warren, Professor of Surgery at the Harvard Medical School (HMS) and President of the American Surgical Association in 1897, was influential in helping to raise the standards of medical education at HMS and elsewhere by increasing the requirements for admission and lengthening the curriculum from 1 to 3 years (Friedmann, 2001).

Dr. William S. Halsted (1852-1922), as Professor of Surgery of the newly opened Johns Hopkins Hospital and Medical School, more than any other surgeon, set the scientific tone for the modern surgery. He introduced a different system of surgical care and resident training, which was referred to as a new "school of surgery". He emphasized research based on anatomic, pathologic, and physiologic principles and animal experimentation. After medical education and scientific research showed when and what operation could be a therapeutic necessity, performed safely and with good clinical results, surgery in general finally achieved the status of a bona fide profession in the early 20th century (Rutkow, 2004).

As the sophistication of surgery grew, national and international surgical societies began to be formed. In America, the most important and influential one was the American College of Surgeons (ACS), founded by Franklin Martin, a Chicago-based gynecologist in 1913. During the centennial celebration of ACS, two books and a pamphlet have been published (Nahrwold \& Kernahan, 2012; American College of Surgeons, 2012 \& 2013). I have summarized ACS's historical accomplishments in the areas of standardization of hospitals, surgical education and certification, cancer and trauma care systems, and surgical quality improvement programs in a separate paper (Lee, 2014).

Among the three ACS publications, the book by Nahrwold and Kernahan (Nahrwold \& Kernahan, 2012) concerned mainly with minutes of meetings of the ACS Board of Regents, polices, and administrative matters. The second publication (American College of Surgeons, 2012) written by chairmen, professors and famous surgeons is a collection of personal thoughts, recollections, and reflections. The book composed of 192 pages. But only four of its 23 chapters had a list of references. The third publication (American College of Surgeons, 2013) did present the surgical improvements and milestones by years. But two of the three publications do not have any index of names of surgeon and/or scientist nor the first new operation and/or surgical approach. It is difficult to find the pearls and tidbits buried between the covers. It is the main objective of this review to help readers to identify such information easily and quickly. Separated by 
major surgical topics, the years that new technique and/or advanced surgical care method were first reported are presented in tabular form and arranged chronologically. When information from the above three ACS publications is quoted in this paper, I have added their original page number(s) to help reader to check the source(s).

\section{Historical Highlights of Cancer Management and Oncological Surgery}

As early as 1920, Dr. Ernest Codman of MGH started the first cancer registry for bone sarcoma based on his "end-result" idea that hospital staffs should follow every patient they treated to determine treatment success and failure (Nahrwold \& Kernahan, 2012: pp. 53-54). He also initiated the first Mortality and Morbidity conference at the MGH in 1924. His original idea and pioneer work has been carried on and expanded by the ACS (American College of Surgeons, 2012: p. 67).

A Committee on Treatment of Malignant Disease was initiated by ACS in1922, later re-named and reorganized as the Commission on Cancer. National Cancer Data Base, a joint program of ACS and the American Cancer Society was formed in 1989. One year after its formation, it began capturing data from all the Commission on Cancer hospital program. Subsequently, it has become the largest tumor registry in the world. Chronological highlights of cancer management and advanced cancer surgical procedures are listed in (Table 1).

It was pure coincidence that two major findings, one clinical (operation for breast cancer) and one basic scientific (angiogenesis) were both reported in the year of 1975. For clinical treatment of breast cancer, the Halsted's paradigm of 1907 that radical mastectomy was necessary was overturned by the many randomized clinical trials (RCT) carried out by the National Surgical Adjuvant Breast Project (NSABP) (American College of Surgeons, 2012: pp. 48, 94). The NSABP was organized and founded by Dr. Bernard Fisher of University of Pittsburg in 1958.

Starting in 1971, 1st RCT of NSABP studied radical mastectomy versus total mastectomy for early breast cancer; 1600 patients were enrolled. Their first report in 1975 showed that the survival rates were statistically similar. A 25-year follow-up report of 2003 confirmed the result. In 1976, comparison of modified radical mastectomy versus lumpectomy \pm radio-therapy, so called "breast conservation therapy (BCT)", was initiated and a 20-year follow-up again showed the results were similar. Subsequent researches have shown that post-operative adjuvant chemotherapy and/or hormonal therapy could improve the survival of such patients even more.

Another important landmark work of Dr. Norman D. Nigro was in designing a multi-modality treatment of squamous cell cancer of the anus, which increased the 5-year survival rate of $50 \%$ with surgery alone to $80 \%$ with chemo-radiotherapy and allowed $85 \%$ of the patients to avoid total proctectomy and permanent colostomy (American College of Surgeons, 2012: p. 107).

In a 1971 New England of Medicine article, Dr. Judah Folkman of HMS postulated that tumors required blood supply to grow and were angiogenesis-dependent. In 1975, he and a graduate student Henry Brem reported the discovery of angiogenesis in cartilage 
Table 1. Chronological highlights of cancer surgery and therapy.

\begin{tabular}{|c|c|}
\hline Year & Events \\
\hline 1920 & $\begin{array}{l}\text { Dr. Ernest Codman of MGH started the 1st cancer registry for bone sarcoma. } \\
\text { He also initiated the 1st Mortality and Morbidity conference in } 1924 \text {. }\end{array}$ \\
\hline 1922 & $\begin{array}{l}\text { The ACS initiated a Committee on Treatment of Malignant Disease. } \\
\text { Later it was re-organized as the Commission on Cancer. }\end{array}$ \\
\hline 1931 & $\begin{array}{l}\text { Dr. Evarts A. Graham performed the 1st successful pneumonectomy } \\
\text { for cancer in a } 48 \text {-year old man who survived for } \\
\text { 30-years after the operation. }\end{array}$ \\
\hline 1935 & $\begin{array}{l}\text { Dr. Allen O. Whipple of Columbia Universitylst performed en-bloc radical } \\
\text { duodeno-pancreactomy for cancer of the pancreas. This "Whipple procedure" } \\
\text { remains one of the few effective treatments against pancreatic cancer today. }\end{array}$ \\
\hline 1939 & $\begin{array}{l}\text { Drs. Alton Ochsner and Michael DeBakey published their study of "Primary } \\
\text { Pulmonary Malignancy" in Surgery Gynecology \& Obstetric, marking } \\
\text { the 1st time tobacco use was linked with lung cancer. }\end{array}$ \\
\hline 1947 & $\begin{array}{l}\text { Dr. Alexander Brunschwig, trained in Boston, France and Chicago, performed } \\
\text { the } 1 \text { st total pelvic exenteration in New York. He did this complex operation } \\
\text { on } 22 \text { terminal patients with advanced cancer localized in the central pelvis. }\end{array}$ \\
\hline 1975 & $\begin{array}{l}\text { Dr. Judah Folkman and graduate student Henry Brem discovered } \\
\text { angiogenesis in cartilage tissue leading to the development of } \\
\text { anti-angiogenic cancer therapy }\end{array}$ \\
\hline 1975 & $\begin{array}{l}\text { Randomized clinical research studies showed that radical mastectomy } \\
\text { should no longer be a standard treatment for breast cancer. }\end{array}$ \\
\hline 1989 & $\begin{array}{l}\text { National Cancer Data Base, a joint program of ACS and the } \\
\text { American Cancer Society was formed. }\end{array}$ \\
\hline
\end{tabular}

tissue, leading to the eventual development of anti-angiogenic therapies not just fighting cancer but also had enormous potential applications in tissue engineering, transplantation and treatment of ischemic state (Friedmann, 2001; American College of Surgeons, 2013: p. 17).

\section{Historical Highlights of Pulmonary, Cardiac, and Vascular Surgery}

In 1933, great advances were made in the field of pulmonary surgery by two thoracic surgeons (American College of Surgeons, 2012: p. 100; American College of Surgeons, 2013: p. 8). Dr. Evarts A. Graham used a tourniquet to perform the first successful pneumonectomy for cancer. The patient, a 48-year man, survived 30 years. Dr. Edward D. Churchill of the MGH was able to safely and selectively remove diseased parts of the lung when the mortality rate from excision of a lobe of the lung was near $50 \%$, due to clumsy techniques and septic complications. Dr. Churchill also was a pioneer in the 
surgery of the parathyroid glands, and performed the first successful pericardiectomy for constrictive pericarditis (Friedmann, 2001). In 1939, Dr. Churchill performed the first segmental lung resection in six patients to extricate tuberculosis, thus conserving the healthy tissue and pulmonary function (American College of Surgeons, 2013: p. 9). In 1950, Dr. Ivor Lewis first reported both an abdominal and a chest approach for esophagectomy (American College of Surgeons, 2012: p. 100). Regarding cardiac surgery, Dr. Elliott C. Cutler, Professor of Surgery at HMS, was the first to operate on the mitral valve in 1923 (Friedmann, 2001). The first operation to correct congenital heart defect was the successful ligation of a patent ductus arteriosus of a 7-year old girl performed by Dr. Robert Gross, chief surgical resident at the Boston Children's Hospital in 1938, while his chief, Dr. William Ladd, was out of town (American College of Surgeons, 2012: p. 100). Later in 1945, Dr. Gross also performed the first successful resection of aortic coarctation with direct anastomosis (Rutkow, 2004). Also in 1945, Dr. Alfred Blalock and pediatric cardiologist Dr. Helen Taussig of Jonhs Hopkins Hospital, reported the first cure of three "blue babies". Such "blue babies" had congenital narrowed pulmonary artery, they became pink after left subclavian artery was divided and anastomosed to the left pulmonary artery.

In 1952, a young Dr. F. John Lewis of University of Minnesota performed the first direct vision open heart operation in the world (American College of Surgeons, 2012: p. 101; American College of Surgeons, 2013: p. 12). Using cross circulation and hypothermia caused asystole, he closed an atrial septal defect (ASD) in a 5-year old girl (Table 2).

Historically, as a medical student in 1940, Michael DeBakey invented the roller pump for use in a direct donor-to-patient transfusion, which became the driving component of the heart-lung machine to provide the patient with continuous blood flow during an open heart procedure (American College of Surgeons, 2013: p. 10). In 1953, after 10yrs of work and eventual collaboration with IBM engineers, Dr. and Mrs. John Gibbon developed a heart lung machine. They performed the first successful open heart operation of 26 minutes to close a congenital ASD. But the IBM machine was too complicated. Richard Dewall, a young surgical assistant of Dr. Walt Lillehei, devised a much simpler and better "Bubbler Oxygenator". Dr. Lillehei used the bubbler oxygenator to successfully perform all types of open heart operation and to promote cardiac surgery more than any other surgeon did then or since (American College of Surgeons, 2012: p. 103).

After heparin was discovered in 1916 by Dr. Jay McLean, Drs. Reynaldo Dos Santos and Egas Moniz developed angiography in 1920 (American College of Surgeons, 2012: p. 185). In 1929, a young German Dr. Werner Frossmann anesthetized his forearm and passed a ureteral catheter all the way into his right ventricle. He then walked down several steps of stairs to the X-ray room and had no problem after dye injected into his ventricle (American College of Surgeons, 2012: p. 105). In 1943, Andre Cournard, a pulmonary physiologist, and Dickson Richard, a Professor of Medicine, both at Columbia University, worked together to develop human cardiac catheterization. These three persons shared the Noble Prize in 1956. 
Table 2. History of cardiac and open heart surgery.

\begin{tabular}{|c|c|}
\hline Year & Events \\
\hline 1923 & $\begin{array}{l}\text { Dr. Elliott C. Cutler performed the 1st successful section } \\
\text { of the stenosed mitral valve. }\end{array}$ \\
\hline 1938 & $\begin{array}{l}\text { Dr. Robert Gross performed the } 1 \text { st cogenital heart defect } \\
\text { correction by ligating a patent ductus arteriosus. }\end{array}$ \\
\hline 1940 & $\begin{array}{l}\text { Dr. Michael DeBakey invented the roller pump, which became the driving } \\
\text { component of the heart-lung machine for open heart procedure. }\end{array}$ \\
\hline 1945 & $\begin{array}{l}\text { Drs. Alfred Blalock and pediatric cardiologist Helen Taussig reported } \\
\text { the 1st cure of three "Blue babies" by operation. }\end{array}$ \\
\hline 1945 & $\begin{array}{l}\text { Dr. Robert Gross performed the 1st successful } \\
\text { correction of aortic coarctation. }\end{array}$ \\
\hline 1952 & $\begin{array}{l}\text { Dr. F. John Lewis of University of Minnesota performed the 1st open } \\
\text { heart operation, using hypothermia, to close an atrial septal } \\
\text { defect (atrial-SD) in a 5-year-old girl. }\end{array}$ \\
\hline 1953 & $\begin{array}{l}\text { After more than } 20 \text {-years of research, Dr. John H. Gibbon used an } \\
\text { extra-corporeal heart-lung machine, developed with IBM, to give a } \\
\text { patient continuous blood flow for } 26 \text { minutes to close an atrial-SD. }\end{array}$ \\
\hline 1954 & $\begin{array}{l}\text { Dr. Clarence W. Lillehei performed the 1st cross-circulation when } \\
\text { the patient's parent served as a living oxygenator. He did } 45 \\
\text { such operations to close ventricular-SD. }\end{array}$ \\
\hline 1964 & $\begin{array}{l}\text { Dr. H. Edward Garrett performed the 1st successful coronary artery } \\
\text { bypass graft (CABG) procedure using a saphenous vein graft } \\
\text { (American College of Surgeons, 2013: p.14) }\end{array}$ \\
\hline 1969 & $\begin{array}{l}\text { Dr. Denton Cooley of Texas 1st successfully implanted } \\
\text { an artificial heart in a patient. }\end{array}$ \\
\hline 1970 & $\begin{array}{l}\text { Dr. William S. Pierce developed the Penn State Heart-Assist Pump, } \\
\text { the 1st surgically implantable pulsatile blood pump } \\
\text { (American College of Surgeons, 2013: p.16) }\end{array}$ \\
\hline
\end{tabular}

In 1958, Dr. Mason Sone of Cleveland Clinic accidently injected $40 \mathrm{cc}$ of dye into a patient's right coronary artery while performing a left ventriculogram. Asystole occurred, but it was corrected by the patient's cough. That episode showed that coronary angiogram was not harmful for the patient and the pictures showing segmental coronary artery disease. This eventually led to the development of coronary artery bypass operations using grafts of saphenous vein or internal mammary artery or endartectomy. Another important medical discovery of the 20th century was that low concentration potassium can cause temporarily cardiac arrest. Thus, surgeons can operate in a still, bloodless heart safely with low risk in all age groups. In fact, about 2000 such operations are performed every 24 hours worldwide (American College of Surgeons, 2012: p. 103).

Abdominal aortic aneurysm (AAA) rupture is a true emergency and is the 13th leading 
cause of death in the US (American College of Surgeons, 2012: p. 187). Early attempts to treat AAA via ligation were unsuccessful until 1923 when Dr. Rudolph Matas (pioneered endoaneurysmorrhaphy in 1888) ligated the aorta both above and below the aneurysm. However, the aneurysm often ruptured months later and by 1940, there were only five recorded cases in which ligation worked. In the 1940s, polyethene cellophane was used to wrap the aorta to induce fibrosis and restrict the growth of the aneurysm. This was done in 1948 to treat the large aneurysm of Dr. Albert Einstein, who lived seven more years (American College of Surgeons, 2012: pp. 185-187). In 1951, French Dr. Charles Dubost performed the first resection of AAA and replaced it with a homograft taken three weeks earlier. This landmark accomplishment led to works by other noted surgeons including the legendary American Dr. Michael E. DeBakey, who used his wife's sewing machine to create the first Dacron graft to treat AAA. In 1944, Dr. John Alexander resected a saccular aneurysm of the thoracic aorta (Rutkow, 2004).

In 1953, Dr. Michael E. DeBakey performed the first carotid endarterectomy on a 53 year old bus driver. In 1954, Dr. Felix Eastcott under the supervision of Dr. Charles Rob successfully performed the first arterectomy for carotid stenosis. In 1961, Dr. Charles Drake of Canada successfully repaired a basilar artery aneurysm in the brain (American College of Surgeons, 2013: pp. 13-14).

In 1948, French Dr. Jean Kunlin, who was a trainee and later an assistant to Dr. Rene Leriche, performed the first successful femoral popliteal bypass with saphenous vein graft. This act transformed the surgical approach to profound lower extremity ischemia. Today, bypass for limb salvage by relieving arterial blockage accounts for as much as half of the operations vascular surgeons perform (American College of Surgeons, 2012: p. 187).

\section{Highlights of Military Surgical Experiences, Care of Trauma and Burn}

During WWI, in one big offensive attack of September to November 1918, the American medical forces treated 69,832 American and 2635 German wounded along with 18,864 gas victims and 2029 shell-shock cases for a total of 93,360 casualties (American College of Surgeons, 2012: p. 171). Another 68,760 were admitted to hospitals, many for influenza. Major medical advances of WWI included: Oswald Hope Robertson championed the first use of blood transfusion; Walter B. Cannon studied shock extensively and published a textbook in 1923, which is appropriate now as it was then; Reconstructive and plastic surgeries were utilized; X-ray machines were used in diagnosis of combat injuries and in treating fractures of gunshot wound; increased importance was placed on orthopedic surgery, physical therapy and rehabilitation (Rutkow, 2004; American College of Surgeons, 2012: p. 171).

The principles of irrigation of wound evolved during WWI and were developed by Henry Dakin, an English chemist and Dr. Alexis Carrel, a French-born American surgeon. Dr. Carrel received a Noble Prize in 1912 for his milestone work in vascular anastomosis (American College of Surgeons, 2012: p. 185). 
In 1924, Drs. Warren H. Cole and Evarts A. Graham co-developed a method to diagnose gall bladder disease using contrast media and $\mathrm{X}$-ray to visualize the gall bladder (American College of Surgeons, 2013: p. 7). This newer scientific technology enabled surgeons to diagnose disease at earlier stage, to locate malignant growth while they are small, and to have more effective post-operative treatment. It also created an influx of surgical patients and helped the growth of surgery (Rutkow, 2004). Subsequent introduction of computed tomography (CT) in 1970s and magnetic resonance imaging (MRI) in 1980s have revolutionized diagnosis and treatment of diseases of all organs in the body (American College of Surgeons, 2012: p. 124).

Dr. Harvey W. Cushing was a dominant surgical figure during the early part of the 20th century. He performed the first brain operation in the US in 1901 (American College of Surgeons, 2013: p. 8). And by 1931, he had completed his 2000th tumor operation. Cushing and W.T. Bovie introduced electrocautery in 1927 (American College of Surgeons, 2012: p. 123). Later with microsurgery, improved operating microscope, and the use of precise bipolar cautery, neurosurgery marked a major paradigm change in the 1960s (American College of Surgeons, 2012: p. 124).

During WWII (1942-1945), as Surgical Consultant to the North Africa and Mediterranean Theater of Operations, Col. Edward D. Churchill, M.D. of HMS led advances in military medicine. He developed the use of delayed primary closure and early debridement of contaminated wounds, and improved the air evacuation process (American College of Surgeons, 2013: p. 11). COL. Churchill also developed the concept of phased wound management for the Army: initial surgery to save life and eradicate infection; reparative surgery minimize disability; reconstructive surgery and rehabilitation (DeBakey, 1996). Experiences and lessons learned from subsequent Vietnam War, Korean War and the skirmishes of Operation Desert Storm in Iraq all contributed not only to military surgery, but also to medical science and civilian patient care (Lee, 1992). Highlights of trauma, military surgical care and newer general operations are listed in (Table 3).

In addition to physical injury, modern care of the patients with burn probably started with the Boston Cocoanut Grove fire on Nov. 28, 1942, in which almost 500 people died (Friedmann, 2001). Dr. Francis D. Moore was on duty as a surgical resident at the MGH that night and the experience led him back to the research laboratory where he studied fluid balance, body composition, and metabolism that eventually led to his major classic textbook, The metabolic care of the surgical patient.

In 1939, Dr. Earl Padget devised an operative dermatome, which allowed calibration of the thickness of skin graft (Rutkow, 2004). Dr. John F. Burke of MGH and HMS, and Ioannis Yannas, $\mathrm{PhD}$, a professor of fibers and polymers at Massachusetts Institute of Technology did 12 years of research and invented artificial skin "Integra" grown from autologus cells to save extensively burned patient in 1981 (Friedmann, 2001; American College of Surgeons, 2013: p. 18).

\section{Endoscopy, Minimal Invasive Surgery and Robot}

From the inception of medicine, physicians and especially surgeons have desired a way 
Table 3. History of military surgery, trauma, and surgery in general.

\begin{tabular}{|c|c|}
\hline Year & Events \\
\hline \multicolumn{2}{|r|}{ (a) Military and trauma Surgery } \\
\hline 1913 & $\begin{array}{l}\text { Dr. Daniel H. Williams successful repaired a stab wound to the } \\
\text { pericardium and the spleen (splenorraphy). }\end{array}$ \\
\hline 1937 & Blood Bank was 1st opened at the Cook County Hospital in Chicago. \\
\hline 1941 & $\begin{array}{l}\text { During WWII, Dr. Charles Drew was in charge of the Plasma for Britain effort. } \\
\text { He advanced techniques to collect, process, and mass produce blood plasma. }\end{array}$ \\
\hline 1942 & $\begin{array}{l}\text { Dr. Isidor S. Ravdin first treated seven severely burned } \\
\text { patients with albumin after the Pearl Harbor attack. }\end{array}$ \\
\hline 1974 & United States implemented nation-wide Emergency Medical System. \\
\hline 1980 & $\begin{array}{l}\text { ACS initiated the Advanced Trauma Life Support (ATLS) course after } \\
\text { famous baseball pitcher Tommy John had a plane crush. }\end{array}$ \\
\hline \multicolumn{2}{|r|}{ (b) Surgery in General } \\
\hline 1924 & $\begin{array}{l}\text { Drs. Warren H. Cole and Ewarts A. Graham 1st used oral contrast } \\
\text { media to diagnose gall ladder disease with } \mathrm{x} \text {-ray. }\end{array}$ \\
\hline 1939 & $\begin{array}{l}\text { Dr. Edward D. Churchill performed the first segmented lung resection to extricate } \\
\text { tuberculosis, thus conserving the healthy tissue and pulmonary function. }\end{array}$ \\
\hline 1966 & $\begin{array}{l}\text { Dr. Edward E. Mason of University of Iowa 1st utilized the undesirable } \\
\text { side effect of weight loss of gastric resection to treat obesity. }\end{array}$ \\
\hline 1966 & $\begin{array}{l}\text { Dr. Stanley J. Dudrick reported on his successful use of only intravenous } \\
\text { feeding to keep an infant alive, growing, and developing for over a year. }\end{array}$ \\
\hline 1981 & $\begin{array}{l}\text { Dr. Michael R. Harrison of San Francisco performed the 1st open fetal } \\
\text { operation to correct a dangerously blocked urinary tract in a fetus. }\end{array}$ \\
\hline
\end{tabular}

to look inside the human anatomy to see and study the inner working of the body. This "look inside" is known as endoscopy.

According to Dr. Jack W. McAninch, an urologist, the first primitive endoscopic instrument debuted in 1806, conceived and made by a German army surgeon, Philipp Bozzini, for the inspection of the pharynx and the nasal cavities (American College of Surgeons, 2012: p. 177). Later development of artificial light (from gas to electricity) and optics (mirrors and lens), lead to the improvement of earlier scopes. In 1877, a German physician Maximilian Nitze designed a cystoscope to inspect the urethra and inside bladder using a water-cooled electric lamp at the tip of the instrument. In 1888, the device became cheaper by using a miniaturized light bulb, which eliminated the need for the cooling system. Fitted with cautery cutting loops and knives, the instrument could remove tumor and cauterize the tumor bed to treat cancer. In 1926, a resectoscope was introduced by urologist Dr. Maximilian Stern of New York.

According to Dr. Gerald Healy, the father of modern endoscopy was Dr. Chevalier Jackson, an otolaryngologist from Philadelphia (American College of Surgeons, 2012: p. 
141). In 1940's, he was the premier instructor teaching techniques for the removal of foreign objects from the upper air and food passages of children and adults. Dr. Jackson also standardized tracheotomy as a safe operation for airway obstruction. In the 1970s, Dr. Heinz R. Stammberger of Austria revolutionized the use of endoscopes to access the sinuses and replaced external sinus surgery (American College of Surgeons, 2012: p. 143). Otolarygologist, neurosurgeon, and plastic surgeon working together with innovative techniques have given new hope to patients with difficult tumors of the skull base. In 1959, Hungarian surgeon Dr. George Berci and Prof. Harold Hopkins, a renowned physicist and professor of applied optics in London launched the Hopkins rod-lens system into endoscopy to improve visibility inside the common bile duct for gall stone (American College of Surgeons, 2013: p. 13).

Laparoscope for insertion into the closed abdominal cavity was pioneered in 1901 by a German Dr. Georg Kelling (American College of Surgeons, 2012: p. 177). According to Dr. Karl C. Podraz, a gynecology oncologist, Dr. Bertram M. Bernhein of Johns Hopkins Hospital first introduced laparoscopy into the US in 1911. And in 1913, Dr. Hans C. Jacobaeus, a Swedish internist, performed the first laparoscopic procedure and reported his finding of abdominal cavity in 19 patients (American College of Surgeons, 2012: p. 113). In the 1930s, Dr. Janos Veres of Hungary improved on the insufflation needle by adding a spring that enabled safe insertion. Dr. Raoul Palmer of France was instrumental in emphasizing the importance of monitoring intraabdominal pressure and used Trendelenburg position to diagnose infertility during WWII. In the 1950s, he introduced a small, safer and brighter quartz light bulb at the tip of the scope, which increased brightness and decrease the chance of burns. Later fiber-optic lightening was used. In 1960s, doctors in Europe performed wider range of laparoscopic gynecologic procedures than in the US (American College of Surgeons, 2012: p. 113). And in the 1960s, the first laparoscopic appendectomy was performed by the German gynecologist, Dr. Kurt Semm (American College of Surgeons, 2012: p. 113). Dr. Semm designed an improved automatic insufflator and thermo-coagulator to prevent tissue from burning during laparoscopic sterilization. In the 1970's, ectopic pregnancies were treated via laparoscope, abetted by the introduction of new television, video camera, and light source technology.

Dr. Philippe Mouret of Lyon, France was credited as performing the first Video cholecystectomy in 1987 (American College of Surgeons, 2012: p. 114). Another publication listed two additional French surgeons: Francois Dubois, and Jacques Perrisat who also borrowed laparoscopic equipment from gynecologists in the 1980's and independently began to perform general surgical procedure-particularly cholecystectomy (American College of Surgeons, 2013: p. 19). By 1990s, this "French technique" quickly gained worldwide acceptance and it is considered as the surgical revolution in the last 25 years (American College of Surgeons, 2012: pp. 50-55). This minimal invasive surgical (MIS) technique has been extended to the examination and resection of almost all intra-thoracic and intra-abdominal organs (Table 4).

With advances in the hardware and software of computer science, operations per- 
formed by automatic mechanical device (robot) have become a clinical reality. In1985, a robot named "Ole", using a software developed by Dr. Yik San Kwoh, assisted in performing a brain biopsy in an area that was difficult to reach by conventional means. In 1992, Dr. Camran Nezhart reported the first laparoscopic radical hysterectomy and lymphadenectomy (American College of Surgeons, 2012: p. 114). Consider the "father of operative video laparoscopy", Nezhart's advances were bolstered by use of the first robotic arm to hold a camera in 1994. In 1998, robot first assisted in the open heart coronary artery bypass graft (CAGB) operation. In 2000, robot assisted in operations of the esophagus and pancreas (Table 4).

In 2001, a "Lindbergh Operation" was demonstrated using a robot doing a cholecystectomy in Paris under the direction of a surgeon in New York. In 2006, first unmanned robotic operation was performed in Milan where a defibrillator was placed in a patient using logics accumulated from thousands of operative data stored in a computer in Boston. In 2008, a robot performed resection of a part of the liver from a person who

Table 4. Minimal invasive and robotic surgery.

\begin{tabular}{|c|c|}
\hline Year & Events \\
\hline \multicolumn{2}{|r|}{ (a) Minimal invasive surgery } \\
\hline 1901 & $\begin{array}{l}\text { German Dr. Georg Kelling pioneered laparoscopy with } \\
\text { advanced fiber-optic lens system. }\end{array}$ \\
\hline 1959 & $\begin{array}{l}\text { Endoscopy for visualize common bile duct and for gall stone removal was } \\
\text { greatly improved through application of the Hopkin's rod-lens system. }\end{array}$ \\
\hline 1987 & $\begin{array}{l}\text { The 1st vido-cholecystectomy was performed by } \\
\text { Dr. Philippe Mouret in France. }\end{array}$ \\
\hline 1992 & $\begin{array}{l}\text { Dr. Camran Nezhart reported the 1st laparoscopic radical } \\
\text { hysterectomy and lymphadenectomy. }\end{array}$ \\
\hline 2007 & First trans-gastric cholecystectomy and first trans-vaginal appendectomy. \\
\hline & (b) Robotic surgery revolution \\
\hline 1985 & $\begin{array}{l}\text { A robot, using a software developed by Dr. Yik San Kwoh, } \\
\text { assisted in performing a brain biopsy. }\end{array}$ \\
\hline 1994 & $\begin{array}{l}\text { Dr. Camran Nezhart, considered the father of operative video-laparoscopy } \\
\text { used the 1st robotic arm to hold a camera/instrument. }\end{array}$ \\
\hline 1998 & $\begin{array}{l}\text { Robot 1st assisted in the open heart coronary artery } \\
\text { bypass graft (CAGB) operation. }\end{array}$ \\
\hline 2000 & Robot 1st assisted in operations of esophagus and pancreas. \\
\hline 2001 & $\begin{array}{c}\text { First "Lindbergh Operation": a robot did a cholecystectomy in } \\
\text { Paris under the direction of a surgeon in New York }\end{array}$ \\
\hline 2006 & $\begin{array}{c}\text { First "Un-manned Operation": a robot placed a defibrillator in a patient in Milan } \\
\text { using logic of thousands of operative data stored in a computer in Boston. }\end{array}$ \\
\hline 2008 & Robot performed resection of part of a liver donated by a person. \\
\hline
\end{tabular}


is the donor. The person did very well and was discharged home two days later.

In 2007, further modification of the usual MIS approach was made by the NOTES (Natural Orifice Trans-lumenal Endoscopic Surgery). NOTES was performed by inserting instrument through natural orifice (mouth, anus, urethra, or vagina), instead of using multiple skin ports for manipulating the surgical instruments. In that year first trans-gastric cholecystectomy and first trans-vaginal appendectomy were performed (American College of Surgeons, 2012: p. 51).

\section{History of Organ Transplantation and Facial Reconstruction}

The first corneal transplantation was performed in 1905 but solid organs were a different matter (American College of Surgeons, 2012: p. 47). In 1909, a French doctor transplanted a rabbit kidney to a young girl who died two weeks later. Another child died with a monkey kidney. In 1913, Dr. Alexis Carrell did canine kidney transplant in American and developed vascular suture technique still in use today.

During the 1940s, Sir Peter Medawar in England performed seminal work on immunology that greatly enhanced our understanding of rejection and eventually led to his 1960 Noble Prize. Of practical importance was the concomitant discovery that radiation and chemotherapy can suppress the immune response. Not only can the initial rejection process be inhibited, but clinical evidence showed that repeated homograft crisis can also be reversed (Lee, 1965).

In 1954, with identical twin brothers serving as donor and recipient, Dr. Joseph Murray of HMS performed the first successful human kidney transplant at Boston's Peter Bent Brigham Hospital. Dr. Murray was awarded the Nobel Prize in 1990. In 1962, Dr. Murray's team also performed the first cadaveric kidney transplant using azathioprine for immuno-suppression (American College of Surgeons, 2013: p. 12). Other organs such as lung, pancreas, liver, heart were also successfully transplanted afterwards (Table 5). In 2008, there were more than 16,000 kidney transplants performed in the US-10,551 from cadaver donors and 5966 from living donors. In the same year, there were 6069 liver transplant, 1800 heart transplant, and 1200 lung transplant performed (American College of Surgeons, 2012: p. 48).

In 1966, Dr. Harvey J. Buncke (father of microsurgery) performed the first great toe-to-thumb transplant in the rhesus monkey (American College of Surgeons, 2012: p. 159). Drs. Shigeo Komatsu and Susumu Tamai did the first human digital re-plantation in 1968. In 1969, Drs. Buncke and Donald McLean transferred the omentum by microvascular technique to fill a large scalp defect in a patient (American College of Surgeons, 2012: p. 159). From there, Dr Buncke went on to many microvascular "firsts", including a great toe-to-thumb transfer in 1972 (American College of Surgeons, 2013: p. 16), serratus muscle transfer for facial paralysis, and tongue replant.

Reconstructive surgery has had dual goals: preservation of life and limb AND restoration of form and function. Over the decades, microsurgery has been continuously re-

fined to produce a superior reconstruction that was aesthetically correct (American College of Surgeons, 2012: p. 161). With the use of MIS and endoscopic techniques, flap 
Table 5. History of allograft and autograft transplantation.

\begin{tabular}{|c|c|}
\hline Year & Events \\
\hline \multicolumn{2}{|r|}{ (a) Allograft transplantation } \\
\hline 1913 & $\begin{array}{l}\text { Early 20th century, Dr. Alexis Carrell transplanted kidney, } \\
\text { heart and spleen in animals. }\end{array}$ \\
\hline 1940’s & Sir Peter Medawar proposed immuno-rejection theory and won Noble Prize. \\
\hline 1954 & Dr. Joseph E. Murray performed the 1st successful human kidney transplant. \\
\hline 1962 & $\begin{array}{l}\text { Dr. Joseph E. Murray also performed 1st cadaveric kidney transplant } \\
\text { and used azathioprine for immuno-suppression. }\end{array}$ \\
\hline 1963 & $\begin{array}{l}\text { Dr. James Hardy performed the 1st lung transplant } \\
\text { (American College of Surgeons, 2012: p. 47) }\end{array}$ \\
\hline 1966 & $\begin{array}{l}\text { Minnesota surgeons performed the 1st human pancreatic transplant } \\
\text { (American College of Surgeons, 2012: p. 47) }\end{array}$ \\
\hline 1967 & Dr. Thomas Starzl of Colorado performed the 1st human liver transplant. \\
\hline 1967 & $\begin{array}{l}\text { Dr. Christian Barnard of South Africa performed the } \\
\text { 1st human heart transplant. }\end{array}$ \\
\hline 1983 & $\begin{array}{l}\text { Dr. Joel Cooper of Toronto performed the 1st successful human lung transplant } \\
\text { and performed the 1st successful double lung transplant 3-years later } \\
\text { (American College of Surgeons, 2013: p. 19) }\end{array}$ \\
\hline \multicolumn{2}{|r|}{ (b) Autograft Transplantation } \\
\hline 1969 & $\begin{array}{l}\text { Dr. Harvey J. Buncke (father of microsurgery) and Dr. Donald McLean 1st } \\
\text { transferred the omentum by microvascular technique to fill a large scalp defect. }\end{array}$ \\
\hline 1972 & Dr. Harvey J. Buncke 1st transplanted a great toe to the thumb. \\
\hline 1974 & $\begin{array}{l}\text { Dr. Frank Jobe performed a pioneering ulnar collateral ligament reconstruction } \\
\text { using tendon-to-ligament grafting for major baseball pitcher Tommy John. }\end{array}$ \\
\hline 2012 & $\begin{array}{l}\text { Dr. Susan McKinnon of St. Louis, performed a ground breaking procedure of } \\
\text { "nerve transfer surgery" on a quadriplegic patient who regained use of his hand. }\end{array}$ \\
\hline
\end{tabular}

tissue can be harvested through smaller incisions and perforator flaps and supra-fascial free flap obtained. Supra-microsurgery is the anastomosis of small caliber vessels ranging from 0.3 to $0.8 \mathrm{~mm}$ in diameter using $12-0$ nylon sutures with 50 - to 30 -um needles.

The ultimate challenge for plastic, reconstructive, and vascular surgery is to restore normal facial tissue and appearance damaged by external trauma and brutal forces. In 1994, Dr. Abraham G. Thomas in India conducted the 1st full-face replant operation on a 9-year-old girl, whose face and scalp were pulled off when her hair was caught in a thresher.

In 2005, French doctors performed the first allograft face transplant. And in 2011, ground breaking face transplant was performed in Boston on a patient whose face was 
destroyed by a chimpanzee 3-year previously. The 20-hour triple transplant operation was performed by a 30 member surgical team. In another teenager girl, whose nose, orbit and check were obliterated by a shotgun blast, surgical procedures included two cheek skin flaps, a three-stage pedicle forehead flap for total external nasal reconstruction. Rib grafts provided internal nasal skeletal support, and a radial forearm microsurgical free tissue was transferred for nasal lining (American College of Surgeons, 2012: p. 161).

Many human organ and/or tissue mal-functions can be replaced or substituted with external or internal medical and surgical devices. As listed in Table 6, some of these devices have replaced surgical approaches with excellent clinical results.

Table 6. Development of medical and surgical devices.

\begin{tabular}{|c|c|}
\hline Year & Events \\
\hline 1961 & $\begin{array}{l}\text { Dr. Thomas J. Fogarty invented and used a balloon embolectomy catheter to } \\
\text { remove blood clots from a patient. The catheter became the 1st MIS surgical } \\
\text { device (American College of Surgeons, 2013: p. 14). }\end{array}$ \\
\hline 1958 & $\begin{array}{l}\text { Sir John Charnley, M.D. perfected the total hip replacement system by introducing two } \\
\text { new materials (bone cement and high density polyethylene). In 1962, he successfully } \\
\text { implanted the 2-component artificial hip joint made of metal and plastic. The joint } \\
\text { was similar to a natural one. After years of research, the Charnley hip has } \\
\text { become a gold standard (American College of Surgeons, 2012: p. 139). }\end{array}$ \\
\hline 1969 & $\begin{array}{l}\text { Dr. Denton Cooley of Texas 1st successfully implanted an artificial heart in a patient, } \\
\text { followed by transplantation of a donor heart that kept him alive for 30-hour } \\
\text { (Nahrwold \& Kernahan, 2012: p. 270). }\end{array}$ \\
\hline 1970 & $\begin{array}{l}\text { Dr. William S. Pierce (thoracic surgeon and chemical engineer) developed the } \\
\text { Penn State Heart-Assist Pump, the 1st surgically implantable pulsatile blood } \\
\text { pump used in thousands of patients worldwide with excellent results } \\
\text { (American College of Surgeons, 2013: p. 16). }\end{array}$ \\
\hline 1972 & $\begin{array}{l}\text { The prototype for the cochlear implant was 1st implanted by Dr. William F. House } \\
\text { (father of neurotology). The device provides hearing for deaf and } \\
\text { hard-of-hearing patients when hearing aids do not work. }\end{array}$ \\
\hline 1973 & $\begin{array}{l}\text { Dr. Lazar J. Greenfield invented a filter to be placed inside the inferior vena cava. } \\
\text { It is the 1st effective method of trapping IVC clots to prevent pulmonary } \\
\text { embolism (American College of Surgeons, 2013: p. 16). }\end{array}$ \\
\hline 1975 & $\begin{array}{l}\text { Dr. Robert H. Bartlett successfully treated an infant with respiratory failure using } \\
\text { extra-corporal membrane oxygenator (ECMO) at the University of California-Irvine. } \\
\text { This accomplishment changed the } 90 \% \text { mortality of neonatal lung failure into } 90 \% \\
\text { survival rate (American College of Surgeons, } 2013: \text { p. } 17 \text { ). }\end{array}$ \\
\hline 1991 & $\begin{array}{l}\text { Dr. Juan Carlos Parodi of Argentina reported the 1st successful endovascular repair } \\
\text { of abdominal aortic aneurysm in five patients. This less invasive approach } \\
\text { represented a quantum change in managing patients with vascular disease } \\
\text { (American College of Surgeons, 2012: p. 189). }\end{array}$ \\
\hline
\end{tabular}




\section{Concluding Remarks}

Surgery, more than any other specialty in medicine, is a team effort. Surgeons use operative procedures to save life and to solve patients' problem. Advances are made with new operations and/or designing and modification of surgical instrument and medical device. Many of the development and innovation resulted from inter-department, interspecialty and multi-disciplinary collaboration. Some of the revolutionary and lasting researches were performed and completed by medical student, residents and/or surgical assistant.

This review is written to celebrate the anniversary of 103th year of American College of Surgeons (ACS) and the 35th year of American Women Society (AWS). This review is not all inclusive and far from complete, because there are many other "surgical firsts" that I could not include due to space limitation. But, with highlights of modern surgical accomplishment and achievement presented here, we can applaud the surgical pioneers in the past and encourage all ACS/AWS members to work toward higher quality of surgery and better quality of life for humanity in the future.

\section{References}

American College of Surgeons Pamphlet (2013). 100 Years of Surgical Quality Improvement (pp. 1-22). Chicago, IL: American College of Surgeons.

American College of Surgeons (2012). Remembering Milestones and Achievements in Surgery: Inspiring Quality for a Hundred Years 1913-2012. Tempa, FL: Faircount Media Group.

DeBakey, M. E. (1996). History, the Torch That Illuminates: Lessons from Military Medicine. Military Medicine, 161, 711-716.

Friedmann, P. (2001). The History of Surgery in Massachusetts. Archives of Surgery, 136, 442447. http://dx.doi.org/10.1001/archsurg.136.4.442

Lee, Y.-T. M. (1992). Operation Desert Storm: Clinical Experiences at the 13th Evacuation Hospital, a Wisconsin National Guard Unit. The Wisconsin Medical Journal, 91, 480-482.

Lee, Y.-T. M. (2014). American College of Surgeons Centennial: Historical Accomplishment and Programs. Tzu Chi Medical Journal, 25, 258-262. http://dx.doi.org/10.1016/j.tcmj.2013.06.004

Lee, Y.-T. N. (1965). Organ Transplantation: A Review of Experimental Studies and Clinical Applications. University of Michigan Medical Journal, 31, 75-82.

Nahrwold, D. L., \& Kernahan, P. J. (2012). A Century of Surgeons and Surgery: The American College of Surgeons 1913-2012. Chicago, IL: American College of Surgeons.

Rutkow, I. M. (2004). Chapter-1 History of Surgery. In: C. M. Townsend, B. M. Evers, \& K. L. Mattox (Eds.), Sabiston Textbook of Surgery: The Biological Basis of Modern Surgical Practice (17th ed., pp. 3-19). Philadelphia: Saunders, an Imprint of Elsevier. 
Submit or recommend next manuscript to SCIRP and we will provide best service for you:

Accepting pre-submission inquiries through Email, Facebook, LinkedIn, Twitter, etc. A wide selection of journals (inclusive of 9 subjects, more than 200 journals)

Providing 24-hour high-quality service

User-friendly online submission system

Fair and swift peer-review system

Efficient typesetting and proofreading procedure

Display of the result of downloads and visits, as well as the number of cited articles

Maximum dissemination of your research work

Submit your manuscript at: http://papersubmission.scirp.org/ 